\title{
Profil Magnetic Resonance Imaging Lumbosakral pada Penderita dengan Nyeri Punggung Bawah di Bagian/Instalasi Radiologi FK Unsrat/RSUP Prof. Dr. R. D Kandou Manado Periode April - Oktober 2019
}

\author{
Ryan D. Wilyo, ${ }^{1}$ Alfa G. E. Y. Rondo, ${ }^{2}$ Vonny N. Tubagus ${ }^{2}$ \\ ${ }^{1}$ Program Studi Pendidikan Dokter Fakultas Kedokteran Universitas Sam Ratulangi Manado \\ ${ }^{2}$ Bagian Radiologi Fakultas Kedokteran Universitas Sam Ratulangi Manado \\ Email: ryandavidwilyo@gmail.com
}

\begin{abstract}
Low back pain (LBP) is still a common health problem. Magnetic resonance imaging (MRI) examination is the best radiological modality if pain originated from soft tissue is suspected. This study was aimed to determine the profile of MRI in patients with LBP. Tjis was a retrospective and descriptive study. Data were obtained from the PACS computer in the Radiology Department. The results obtained 112 patients with MRI examination. Most patients were female as many as 59 patients $(51.75 \%)$, and the most frequent age group was > 50 years as many as 69 patients $(60.53 \%)$. The most common MRI diagnosis was disc herniation of bulging type in 86 patients $(76.78 \%$ ) especially in L4-L5 and L5-S1, followed by spinal canal stenosis in 49 patients $(43.75 \%)$, ligamentum flavum hypertrophy in 44 patients (39.28\%), and nerve root compression in 40 patients (35.71\%). In conclusion, the most common profile of MRI diagnosis among patients with LBP was disc herniation of bulging type located in L4-L5 and L5-S1, followed by spinal canal stenosis, ligamentum flavum hypertrophy, dan nerve root compression.
\end{abstract}

Keywords: low back pain, magnetic resonance imaging

\begin{abstract}
Abstrak: Nyeri punggung bawah (NPB) masih merupakan masalah kesehatan yang sering terjadi. Pemeriksaan magnetic resonance imaging (MRI) merupakan modalitas radiologis terbaik bila dicurigai nyeri berasal dari jaringan lunak. Penelitian ini bertujuan untuk mengetahui profil MRI pada penderita dengan NPB. Jenis penelitian ialah deskriptif retrospektif. Data diperoleh melalui komputer PACS di Bagian Radiologi Fakultas Kedokteran Universitas Sam Ratulangi Manado. Hasil penelitian mendapatkan 112 pasien dengan diagnosis MRI, yang terbanyak ialah perempuan berjumlah 59 orang $(51,75 \%)$. Kelompok usia yang paling sering ialah >50 tahun sebanyak 69 pasien (60,53\%). Profil MRI yang paling banyak ditemukan berupa herniasi diskus pada 86 pasien $(76,78 \%)$ dengan tipe terbanyak ialah bulging, dan lokasi tersering pada L4-L5 dan L5-S1, diikuti oleh stenosis kanalis spinalis 49 pasien $(43,75 \%)$, hipertrofi ligamentum flavum 44 pasien $(39,28 \%)$, dan kompresi akar saraf 40 pasien $(35,71 \%)$. Simpulan penelitian ini ialah profil MRI pada pasien dengan NPB yang terbanyak ialah herniasi diskus dengan tipe bulging pada L4-L5 dan L5-S1, diikuti oleh stenosis kanalis spinalis, hipertrofi ligamentum flavum, dan kompresi akar saraf.
\end{abstract}

Kata kunci: nyeri punggung bawah, magnetic resonance imaging

\section{PENDAHULUAN}

Nyeri punggung bawah atau low back pain (NPB, LBP) merupakan masalah kesehatan yang sering terjadi di Indonesia. Nyeri punggung bawah biasanya menimbulkan rasa nyeri pada punggung bawah, baik unilateral maupun bilateral. ${ }^{1}$

Penyebab NPB diklasifikasikan atas spesifik dan nonspesifik. Penyebab spesifik antara lain, fraktur vertebra, infeksi, dan tumor sedangkan yang nonspesifik $(85 \%)$ disebabkan oleh kelainan pada jaringan 
lunak yaitu cedera otot, ligamen, spasme atau keletihan otot yang dikaitkan dengan duduk terlalu lama, posisi duduk yang kurang ergonomis, usia, jenis kelamin, indeks massa tubuh, dan kebiasaan olahraga. ${ }^{2}$

Di Indonesia, hasil penelitian menunjukkan bahwa prevalensi NPB yang timbul setelah menjadi mahasiswa jurusan Ortotik Prostetik Politeknik Kesehatan Surakarta ialah 32,2\%. Faktor risiko yang berhubungan dengan NPB ialah kebiasaan olahraga, kebiasaan berdiri, kebiasaan mengangkat, dan stres, sedangkan faktor risiko yang tidak berhubungan secara bermakna yaitu jenis kelamin, indeks massa tubuh dan kebiasaan duduk. $^{3}$ Di Manado, penelitian oleh Umboh et $\mathrm{al}^{4}$ terhadap pasien dengan NPB di ruang rawat inap RSU GMIM Pancaran Kasih menyimpulkan bahwa tidak terdapat hubungan antara NPB dengan jenis kelamin dan juga dengan kelompok usia.

Metode pencitraan magnetic resonance imaging (MRI) menjadi teknik pencitraan dengan opsional terakhir meskipun telah digunakan secara luas dan dapat memberikan manfaat dalam penegakan diagnosis dari gejala NPB bila dicurigai adanya kelainan pada jaringan lunak. Keunggulan MRI dibandingkan modalitas lainnya yaitu memiliki resolusi kontras jaringan lunak yang lebih baik dan dapat terlihat hingga cairan serebrospinal, meskipun pada penderita dengan pacu jantung (pacemaker), klip aneurisma, implan koklea/stapes, serta beberapa kondisi lain yang merupakan kontraindikasi pemeriksaan lain. Magnetic resonance imaging juga memerlukan waktu pemeriksaan yang lebih lama, sehingga sulit diaplikasikan pada penderita yang tidak kooperatif atau tidak stabil. ${ }^{5}$

Berdasarkan latar belakang yang telah diuraikan maka peneliti tertarik untuk mengetahui profil MRI pada penderita dengan NPB berdasarkan kelompok usia, jenis kelamin, dan diagnosis MRI dengan menggunakan data pasien NPB dari Bagian/Instalasi Radiologi FK Unsrat RSUP Prof. Dr. R. D. Kandou Manado selama periode April 2019 - Oktober 2019.

\section{METODE PENELITIAN}

Pada penelitian ini digunakan semua foto pemeriksaan yang menunjukkan profil MRI lumbosakral pada pasien dengan gejala klinis NPB di Bagian/Instalasi Radiologi RSUP Prof. Dr. R.D Kandou Manado pada periode April 2019 - Oktober 2019. Jenis penelitian ialah deskriptif retrospektif dengan menggunakan data sekunder berupa foto pencitraan pasien dengan gejala klinis NPB. Sampel penelitian ini diperoleh dengan menggunakan total sampling. Data penelitian mencakup jenis kelamin, usia, stenosis kanalis spinalis, herniasi diskus, hipertrofi ligametum flavum, dan kompresi akar saraf.

Penelitian ini telah mendapat persetujuan dari Komisi Etik Penelitian Kesehatan RSUP Prof. Dr. R. D. Kandou Manado, dengan nomor keterangan layak etik yaitu No. 038/EC/KEPK-KANDOU/X/2019.

\section{HASIL PENELITIAN}

Selama periode April - Oktober 2019, didapatkan pasien NPB yang dilakukan pemeriksaan MRI sebanyak 112 orang terdiri dari 55 orang laki-laki $(48,25 \%)$ dan 57 orang perempuan $(51,75 \%)$. Terlihat bahwa jumlah pasien untuk kedua jenis kelamin tidak banyak berbeda.

Tabel 1 memperlihatkan penggolongan usia pada pasien NPB yang dilakukan pemeriksaan MRI lumbosakral, dibagi menjadi 5 kelompok yaitu <20 tahun, 2030 tahun, 31-40 tahun, 41-50 tahun, dan $>50$ tahun. Jumlah terbanyak terdapat pada kelompok usia $>50$ tahun yaitu 69 pasien $(61,52 \%)$.

Tabel 1. Distribusi pasien NPB berdasarkan kelompok usia

\begin{tabular}{ccc}
\hline $\begin{array}{c}\text { Usia } \\
\text { (tahun) }\end{array}$ & $\mathbf{n}$ & $\begin{array}{c}\text { Persentase } \\
(\%)\end{array}$ \\
\hline$<20$ & 8 & 7,14 \\
$20-30$ & 9 & 8,03 \\
$31-40$ & 11 & 9,82 \\
$41-50$ & 15 & 13,39 \\
$>50$ & 69 & 61,62 \\
Total & 112 & 100 \\
\hline
\end{tabular}

Tabel 2 memperlihatkan distribusi 
pasien NPB dengan diagnosis MRI berdasarkan kelompok usia. Terlepas dari derajat $0 /$ normal, pasien dengan derajat stenosis kanalis spinalis derajat 3 terbanyak pada usia $>50$ tahun.

Tabel 2. Distribusi pasien NPB berdasarkan kategori usia dan stenosis kanalis spinalis

\begin{tabular}{|c|c|c|c|c|c|}
\hline \multirow{2}{*}{$\begin{array}{c}\text { Kategori } \\
\text { usia } \\
\text { (tahun) }\end{array}$} & \multicolumn{4}{|c|}{$\begin{array}{l}\text { Derajat stenosis } \\
\text { kanalis spinalis }\end{array}$} & \multirow[t]{2}{*}{$\begin{array}{c}\text { Jumlah } \\
\text { (n) }\end{array}$} \\
\hline & 0 & 1 & 2 & 3 & \\
\hline$<20$ & 8 & & & & 8 \\
\hline $20-30$ & 6 & 1 & & 2 & 9 \\
\hline $31-40$ & 8 & 1 & & 2 & 11 \\
\hline $41-50$ & 11 & 4 & & & 15 \\
\hline$>50$ & 30 & 25 & 8 & 6 & 69 \\
\hline
\end{tabular}

Tabel 3 memperlihatkan bahwa pasien NPB dengan hasil pemeriksaan MRI lumbosakral terbanyak ialah gambaran herniasi diskus berjumlah 86 orang kategori bulging, diikuti protusi, ekstrusi, dan ekstrusi dengan sekuestrasi herniasi diskus terutama pada L4-L5 dan L5-S1.

Tabel 3. Distribusi pasien NPB berdasarkan gambaran herniasi diskus

\begin{tabular}{ccc}
\hline Herniasi diskus & n & \% \\
\hline Bulging & & \\
L1-L2 & 19 & 9,01 \\
L2-L3 & 23 & 10,91 \\
L3-L4 & 28 & 13,27 \\
L4-L5 & 47 & 22,27 \\
L5-S1 & 43 & 20,39 \\
Protusi & & \\
L1-L2 & 3 & 1,42 \\
L2-L3 & 5 & 2,37 \\
L3-L4 & 7 & 3,32 \\
L4-L5 & 20 & 9,48 \\
L5-S1 & 12 & 5,68 \\
Ekstrusi & & \\
L3-L4 & 1 & 0,47 \\
L4-L5 & 1 & 0,47 \\
Ekstrusi & & \\
dengan sekuestrasi & & \\
L4-L5 & 1 & 0,47 \\
L5-S1 & 1 & 0,47 \\
Total & 211 & 100 \\
\hline
\end{tabular}

Tabel 4 memperlihatkan distrtibusi pasien NPB berdasarkan kategori usia dan degenerasi diskus. Terdapat 72 pasien yang didiagnosis degenerasi diskus. Yang terbanyak ialah kategori usia >50 tahun dengan degenerasi diskus sebanyak 57 pasien sedangkan diskus normal terdapat sebanyak 12 pasien.

Tabel 4. Distribusi pasien NPB berdasarkan kategori usia dan degenerasi diskus

\begin{tabular}{ccc}
\hline Kategori usia & \multicolumn{2}{c}{ Gambaran diskus } \\
& $\begin{array}{c}\text { Degenerasi } \\
\text { diskus }\end{array}$ & Normal \\
\hline$<20$ & 1 & 7 \\
$20-30$ & 1 & 8 \\
$31-40$ & 6 & 5 \\
$41-50$ & 7 & 8 \\
$>50$ & 57 & 12 \\
Total & 72 & 40 \\
\hline
\end{tabular}

Tabel 5 memperlihatkan distribusi pasien NPB berdasarkan kategori usia dan gambaran ligamentum flavum. Terdapat 44 pasien yang didiagnosis hipertrofi ligamentum flavum. Yang terbanyak ialah kategori usia >50 tahun dengan hipertrofi ligamentum flavum sebanyak 38 pasien sedangkan ligamentum flavum normal terdapat sebanyak 31 pasien.

Tabel 5. Distribusi pasien NPB berdasarkan kategori usia dan gambaran ligamentum flavum

\begin{tabular}{|c|c|c|}
\hline \multirow[t]{2}{*}{$\begin{array}{l}\text { Kategori usia } \\
\text { (tahun) }\end{array}$} & \multicolumn{2}{|c|}{$\begin{array}{c}\text { Gambaran } \\
\text { ligamentum flavum }\end{array}$} \\
\hline & Hipertrofi & Normal \\
\hline$<20$ & 1 & 7 \\
\hline $20-30$ & 1 & 8 \\
\hline $31-40$ & 1 & 10 \\
\hline $41-50$ & 3 & 12 \\
\hline$>50$ & 38 & 31 \\
\hline Total & 44 & 58 \\
\hline
\end{tabular}

Tabel 6 memperlihatkan distribusi pasien NPB berdasarkan kategori usia dan gambaran akar saraf. Terdapat 40 pasien yang didiagnosis kompresi akar saraf. Yang terbanyak ialah kategori usia >50 tahun dengan kompresi akar saraf sebanyak 32 pasien sedangkan gambaran akar saraf normal terdapat sebanyak 37 pasien. 
Tabel 6. Distribusi pasien NPB berdasarkan kategori usia dan gambaran akar saraf

\begin{tabular}{ccc}
\hline Kategori usia & \multicolumn{2}{c}{ Gambaran akar saraf } \\
& Kompresi & Normal \\
\hline$<20$ & 1 & 7 \\
$20-30$ & 2 & 7 \\
$31-40$ & 2 & 9 \\
$41-50$ & 3 & 12 \\
$>50$ & 32 & 37 \\
Total & 40 & 72 \\
\hline
\end{tabular}

Tabel 7 memperlihatkan distribusi pasien NPB berdasarkan kategori usia dan tidak terlihat kelainan pada gambarn MRI. Jumlah terbanyak terdapat pada usia $<20$ tahun dan 20-30 tahun.

Tabel 7. Distribusi pasien NPB berdasarkan kategori usia dan tidak terlihatnya kelainan pada gambaran MRI

\begin{tabular}{cc}
\hline $\begin{array}{c}\text { Kategori usia } \\
\text { (tahun) }\end{array}$ & $\begin{array}{c}\text { Tidak terlihat } \\
\text { kelainan }\end{array}$ \\
\hline$<20$ & 7 \\
$20-30$ & 6 \\
$31-40$ & 1 \\
$41-50$ & 1 \\
$>50$ & 2 \\
Total & 17 \\
\hline
\end{tabular}

\section{BAHASAN}

Selama periode April-Oktober 2019, didapatkan jumlah pasien NPB yang dilakukan pemeriksaan MRI sebanyak 112 orang, terdiri dari 55 orang laki-laki $(48,25 \%)$ dan 57 orang perempuan $(51,75 \%)$. Terlihat bahwa jumlah pasien untuk kedua jenis kelamin hampir sama. Hal ini didukung oleh penelitian Nabila ${ }^{6}$ yang menyatakan bahwa tidak terdapat hubungan antara jenis kelamin dengan penderita specifik dan non specifik NPB.

Penggolongan usia pada pasien NPB yang dilakukan pemeriksaan MRI lumbosakral, dibagi menjadi 5 kelompok yaitu $<20$ tahun, 20-30 tahun, 31-40 tahun, 4150 tahun, dan $>50$ tahun. Terlihat bahwa jumlah pasien NPB bertambah seiring dengan bertambahnya usia dengan jumlah terbanyak pada kelompok usia >50 tahun yaitu 69 pasien $(61,52 \%)$. Hal ini menunjukkan bahwa NPB merupakan masalah degeneratif. Hasil penelitian ini juga didukung oleh penelitian yang dilakukan Arham $^{7}$ di pelabuhan Manado yang mendapatkan 1 orang $(1,7 \%)$ kelompok usia $<25$ tahun dan meningkat pada kelompok usia 25-35 tahun sebanyak 20 orang $(33,3 \%)$, selanjutnya tertinggi ditemukan pada kelompok usia $>35$ tahun sebanyak 39 orang $(65 \%)$, dengan simpulan terdapat hubungan antara usia dengan NPB.

Hasil penelitian ini mendapatkan bahwa semakin bertambahnya usia pada pasien NPB, semakin besar kemungkinan terjadinya stenosis kanalis spinalis (Tabel 2). Hal ini selaras dengan pernyataan Suyasa ${ }^{8}$ yaitu stenosis kanalis spinalis lebih berpeluang terjadi pada pasien yang berusia tua atau oleh proses penuaan karena diakibatkan penyempitan saluran tengah tulang belakang yang bersifat progresif.

Hasil penelitian ini mendapatkan bahwa pasien NPB dengan hasil pemeriksaan MRI lumbosakral terbanyak ialah gambaran herniasi diskus berjumlah 86 orang kategori bulging, diikuti protusi, ekstrusi, dan ekstrusi dengan sekuestrasi (Tabel 3). Hasil ini selaras dengan penelitian oleh Azhaduddin ${ }^{6}$ yang menyatakan bahwa sebagian besar kasus herniasi diskus $(95 \%)$ terjadi di daerah lumbar, diikuti oleh daerah servikal dan torakal sekitar 0,5-4\% dari semua kasus. Selain itu, penelitian ini juga mendapatkan bahwa sebagian besar pasien memiliki herniasi diskus pada L4-L5 diikuti oleh L5-S1 dan L2-L3. Hasil ini juga sejalan dengan penelitian Azhaduddin ${ }^{6}$ yang menyatakan bahwa tingkat paling umum yang terlibat dalam herniasi lumbar ialah L4-L5 diikuti oleh L5-S1.

Hasil penelitian ini mendapatkan 72 pasien yang didiagnosis degenerasi diskus, yang terbanyak ialah kategori usia $>50$ tahun (Tabel 4). Menurut Suyasa ${ }^{8}$ terdapat kenaikan jumlah pasien dengan degenerasi diskus berdasarkan kategori usia dikarenakan proses pernuaan bersama dengan mikrotrauma dan gangguan faktor nutrisi diskus. 
Berdasarkan kategori usia dan gambaran ligamentum flavum didapatkan 44 pasien yang didiagnosis hipertrofi ligamentum flavum dan yang terbanyak ialah kategori usia >50 tahun (Tabel 5). Demikian pula, berdasarkan kategori usia dan gambaran akar saraf didapatkan 40 pasien yang didiagnosis kompresi akar saraf dan yang terbanyak ialah kategori usia >50 tahun (Tabel 6). Dari penelitian ini, dapat disimpulkan bahwa hipertrofi ligamentum flavum dan kompresi akar saraf bersifat degeneratif.

Pada penelitian ini terdapat kelainan yang tidak dapat diidentifikasi atau gambaran MRI yang terlihat normal sebanyak 17 pasien (15,17\%) (Tabel 7). Hasil penelitian oleh Rahmatika ${ }^{9}$ menyatakan bahwa NPB dapat terjadi karena faktor psikogenik seperti histeria, depresi, atau kecemasan dan faktor nyeri yang berasal dari organ lain seperti hati, kandung empedu, paankreas, rahim, ovarium, atau kandung kemih.

\section{SIMPULAN}

Profil MRI pada pasien dengan NPB yang terbanyak ialah herniasi diskus dengan tipe bulging pada L4-L5 dan L5-S1, diikuti oleh stenosis kanalis spinalis, hipertrofi ligamentum flavum, dan kompresi akar saraf.

\section{Konflik Kepentingan}

Penulis menyatakan tidak terdapat konflik kepentingan dalam studi ini.

\section{DAFTAR PUSTAKA}

1. Cahyono B. Hubungan gejala klinis pasien low back pain dengan karakteristik gambaran foto polos lumbosacral AP lateral di RSUD Saras Husada Purworejo [Skripsi]. Yogyakarta: FKU UMY; 2015.

2. Umami AR, Hartatnti RI, Dewi A. Hubungan antara karakteristik responden dan sikap kerja duduk dengan keluhan nyeri punggung bawah pada pekerja batik tulis. Pustaka Kesehatan. 2014;21:72-8.

3. Wulandari M, Setyawan D, Zubaidi A. Faktor risiko low back pain pada mahasiswa jurusan ortotik prostetik politeknik kesehatan Surakarta. Kementerian Kesehatan Politeknik Kesehatan Surakarta Jurusan Ortotik Prostetik; 2017;2(1).

4. Umboh B, Rattu JAM, Adam H. Hubungan antara karakteristik individu dengan keluhan nyeri punggung bawah pada perawat di ruang rawat inap RSU GMIM Pancaran Kasih Manado. Kesmas. 2017;6(3).

5. Panduwinata W. Peranan magnetic resonance imaging dalam diagnostic nyeri punggung bawah kronik. CDK. 2014; 41(4):260-3.

6. Azharuddin. Surgical of limbar disc herniation at zainoel abidin general hospital Banda Aceh: Experience with 28 patients. Banda Aceh: Jurnal Kedokteran Syiah Kuala. 2014;4:149.

7. Arham AS. Hubungan antara umur, masa kerja dan lama kerja terhadap nyeri punggung bawah pada tenaga kerja bongkar muat di pelabuhan Manado. Jurnal Fakultas Kesehatan Masyarakat Universitas Sam Ratulangi. 2015.

8. Suyasa IK. Penyakit Degenerasi Lumbal Diagnosis dan Tatalaksana. Denpasar: Udayana University Press.2018

9. Rahmatika M. pengaruh masa, durasi, dan pisis bekerja terhadap kelihan low back pain pada pekerja pengemasan PT Phapros [Tesis]. Semarang: Universitas Muhammadiyah Semarang; 2016. 